\title{
International transfer pricing in business, economics, and teaching
}

Citation for published version (APA):

Broecker, T. (1997). International transfer pricing in business, economics, and teaching. Universiteit Maastricht. https://doi.org/10.26481/spe.19971121tb

Document status and date:

Published: 21/11/1997

DOI:

10.26481/spe.19971121tb

Document Version:

Publisher's PDF, also known as Version of record

\section{Please check the document version of this publication:}

- A submitted manuscript is the version of the article upon submission and before peer-review. There can be important differences between the submitted version and the official published version of record.

People interested in the research are advised to contact the author for the final version of the publication, or visit the DOI to the publisher's website.

- The final author version and the galley proof are versions of the publication after peer review.

- The final published version features the final layout of the paper including the volume, issue and page numbers.

Link to publication

\footnotetext{
General rights rights.

- You may freely distribute the URL identifying the publication in the public portal. please follow below link for the End User Agreement:

www.umlib.nl/taverne-license

Take down policy

If you believe that this document breaches copyright please contact us at:

repository@maastrichtuniversity.nl

providing details and we will investigate your claim.
}

Copyright and moral rights for the publications made accessible in the public portal are retained by the authors and/or other copyright owners and it is a condition of accessing publications that users recognise and abide by the legal requirements associated with these

- Users may download and print one copy of any publication from the public portal for the purpose of private study or research.

- You may not further distribute the material or use it for any profit-making activity or commercial gain

If the publication is distributed under the terms of Article $25 \mathrm{fa}$ of the Dutch Copyright Act, indicated by the "Taverne" license above, 


\title{
International transfer pricing in business, economics, and teaching
}

\author{
INAUGURAL LECTURE \\ held at the acceptance of the position \\ of professor in quantitative economics \\ at the University of Maastricht \\ on Friday 21 November, 1997
}

by

Dr. Dr. Thorsten Broecker 


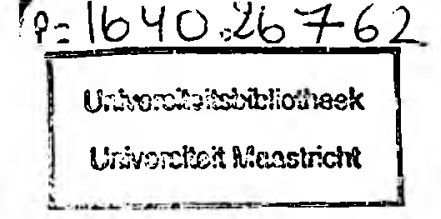

Dear Rector,

Dear Ladies and Gentlemen,

It is my honour and pleasure to be able to teach at the University of Maastricht on the subject of International Transfer Pricing. Therefore, today, I would like to explore with you this topic of international transfer pricing and its role in business, economics, and teaching.

Intemational transfer pricing deals with the valuation of transfers of goods, services and intangibles between the affiliated companies of a multinational enterprise. It determines largely the distribution of profits amongst the group companies and therefore the tax returns in their host countries. With the globalization of the economy and of individual companies, this issue has become a focus of attention for the OECD member states, amongst them The Netherlands, and in 1995 new OECD Guidelines were published on international transfer pricing. This indicates that countries and multinational enterprises alike recognize the increased importance of transfer pricing.

International transfer pricing is furthermore a truly interdisciplinary subject, in that it requires an economic and business interpretation of the law and the political objectives behind it. Still, I believe that there are areas, which are interesting from an economics and business perspective, but which have not yet attracted the academic interest they deserve. I do hope that my speech will further stimulate and foster interdisciplinary work on this subject.

For nearly the same reasons, courses on international transfer pricing provide substantial educational benefits for students in economics and business administration and law. In fact, insights and tools will help them in their professional careers.

For my own person, I see my work at the University of Maastricht as a complement to my work as a management consultant on, amongst other financial subjects, solving 
international transfer pricing issues for multinational enterprises. It is an opportunity for me to take a look at the broader picture. I will do this today in my speech where I want to present my personal views and thoughts on the economic principles and their application in international transfer pricing. Despite having worked a substantial portion of my career in this area, I am still fascinated by the subject. And I hope that you will share my interest in international transfer pricing after my speech.

\section{International transfer pricing has gained in importance for multinational enterprises}

\section{There are substantial cross-border transaction flows between the members of a} multinational enterprise

International transfer pricing is first of all an issue that arises for multinational enterprises. It addresses the question of how to properly price transactions between the affiliated companies of the multinational enterprise which are located in different countries.

Let me give you an example: you buy a computer in The Netherlands. This type of computer, however, may have been technically designed in the US, assembled in the UK, with components coming from even other countries. All companies involved may belong to the same multinational enterprise. So what should these companies get for their share of design, manufacturing and marketing work they contributed to the computer you bought, and what is a fair share of the tax retums for each of the host countries?

This clearly depends on many factors, one of which is the international structure of the group's value added activities and its transaction flows. Multinational enterprises optimize their resource structure when operating in geographical regions or on a global scale, whilst optimally serving the individual markets. This has consequences for their 
research and development, production and distribution network. Typically, on a regional basis, research and development for a specific product is concentrated in one location, the production of semi-finished goods and finished goods is carried out in a few locations, and sales and marketing companies are established in every local market. Furthermore, all these entities may be supported by shared service centres, which provide support to the operating units for accounting, treasury, human resources or other functions. This resource structure and the distribution of the value added activities in the multinational enterprise is determined, for example, by considerations of factor costs, logistics, the availability of a skilled labour force, and the exploitation of economies of integration.

Not surprisingly, there are substantial cross-border transaction flows between the entities of the multinational enterprise. Semi-finished goods flow from their production locations to the production locations of finished goods. They in turn are shipped to the sales and marketing companies. But it is not only the transfer of tangible goods within the multinational enterprise that is important. Equally important are transfers of intangibles and services. An example of an intangible is the result of product or process development, that is made available by the research and development centre to the production units. Other examples are marketing intangibles, e.g. trade or brand names that are often developed centrally but used by all the local sales companies. For every Guilder of sales to the customers of the multinational enterprise, 50 Cents of inter-company transactions might easily be incurred. 


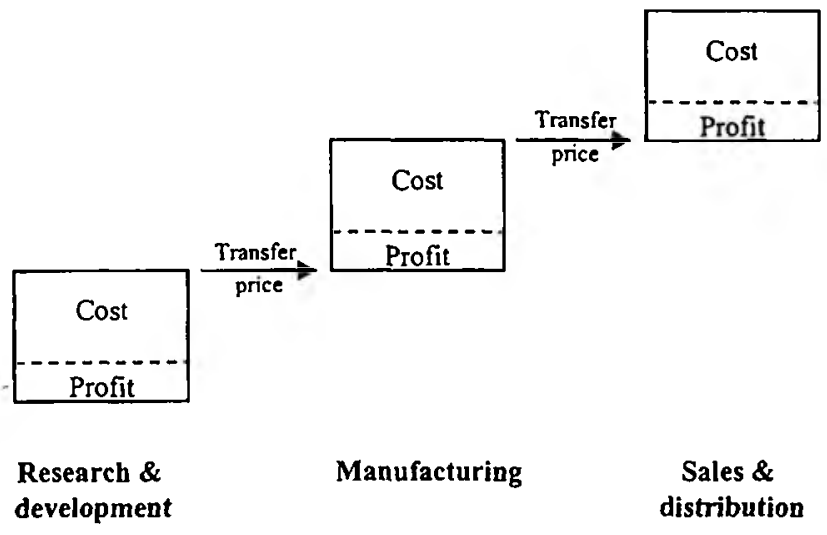

Transaction flow within a multinational enterprise

The cross-border transactions within a multinational enterorise create a tax problem

Clearly all these intra-group transactions between the entities of the multinational enterprise have to be priced. Unless these transfer prices are used to provide the right incentives in a profit centre organization, a topic which I do not want to pursue here, they are not directly important for the multinational enterprise. The transfer prices merely affect the distribution of the group's operating profit amongst its entities but not its overall level. This is the reason why some people refer to transfer prices as "wooden dollars" or shifting money from one pocket to another.

Transfer prices create, however, a tax problem precisely because of their effect on the distribution of the group's operating profit amongst its entities. Obviously, if the transfer price for goods, services or intangibles is set higher, then the selling entity will receive a higher portion of the entire operating profit and the buying entity will receive a smaller 
portion. This in turn affects the tax income that each of the host countries receives from the operation of the multinational enterprise.

Tax authorities are therefore concerned that they do not receive a fair share of the group's taxable income. The primary issue is not even that multinational enterprises deliberately use their transfer pricing to exploit the tax differentials between the various countries. According to my experience, tax efficiency is one amongst many other and often more important factors that drive investment and resource allocation decisions. Rather, because of its relatively low importance, transfer pricing does not receive the necessary attention which can lead to distortions in the distribution of profits. This is the reason why tax authorities are allowed to adjust transfer prices and tax the resulting profits even if tax avoidance is not intended.

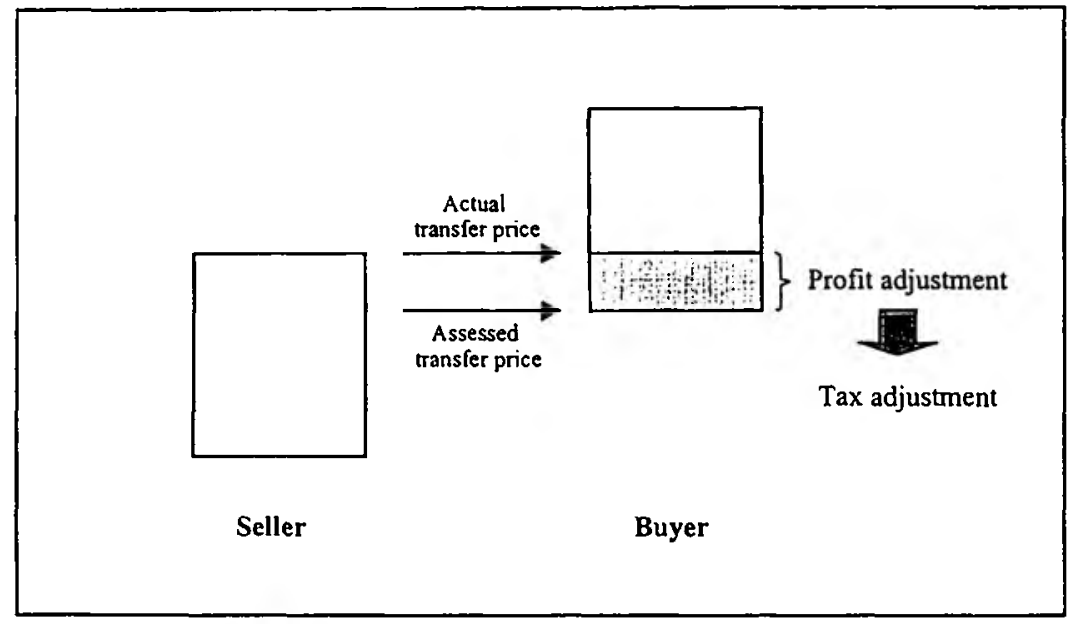

Tax adjustment due to transfer price adjustment

The tax authorities have recognized that the investigation of transfer pricing is becoming an important source of tax revenues. This emanates also from the recent publication of 
the US Regulations and the OECD Guidelines on international transfer pricing in 1995 and the controversial debates about the principles of international transfer pricing and its interpretations.

Today we are in a situation of increased awareness about transfer pricing problems, higher sophistication of methods and data analysis, and an ever increasing importance of multinational enterprises for international transactions.

In this situation, multinational enterprises face the task of designing and implementing transfer pricing systems that are tax acceptable to avoid costly litigation or even double taxation. Such a system has to be tailored to the enterprise's strategy and structure. More precisely, the transfer pricing system has to properly reflect the functions carried out, the assets and resources employed and the risks taken by the group companies involved in these intercompany transactions. This is the reason why, in addition to legal considerations, business reasoning and the application of economic principles and tools come into play.

Economic and business principles underlie the approaches in international transfer pricing

The governing principle in international transfer oricing is the arm's length standard

In this section, I want to outline which economic principles underlie today's approaches to international transfer pricing. The starting point for this discussion is the internationally accepted Arm's Length Standard, which sets out under which conditions a transfer pricing system is tax acceptable. The US Regulations on transfer pricing provide a very concise definition: 
Under the arm's length standard controlled taxpayers are expected to realize from their controlled transactions the results that would have been realized if uncontrolled taxpayers had engaged in the same transactions under the same circumstances.

\section{The questions of comparabilitv and comparabilitv adiustments arise}

This definition of the amm's length standard raises certain questions: What is meant by "result", and how can it be measured? This leads to the various possible transfer pricing methods. The typical methods for transactions of tangible property are:

- Comparable uncontrolled price method which compares the transfer price directly with market prices,

- Resale price method which compares a controlled taxpayer's gross margin, i.e. the difference between net sales and cost of sales expressed as percentage of sales, with the gross margins of other companies,

- Cost plus method, which compares the taxpayer's markup on cost with those of other companies,

- Transactional net margin method, which compares the taxpayer's net margin with those of other companies. This method can be applied in connection with the resale price or the cost plus logic.

- Profit split method, which splits the consolidated profit of the multinational enterprise that is related to the specific intercompany transactions under consideration according to the contribution of each party to the group's success.

The typical transfer pricing methods for the transfer of intangibles are:

- Licensing, where the licensor receives an income from the licensee for allowing the licensee to exploit proprietary product, process or marketing intangibles. Under licensing, one can, for example, compare the licensing agreement and the royalty rate in the controlled transaction with those in uncontrolled transactions between independent parties. Or, one can apply the profit split method that splits the 
consolidated profit from using the intangible and determines the royalty as that portion of the total profit that accrues to the licensor.

- Cost sharing, where the cost sharing parties fund the development of the intangible and bear the potential risk of failure of the development

The second question is: How can one identify and analyze "same transactions under the same circumstances"? And more importantly: If there are differences in the transactions and the circumstances how can one properly account for these differences? These questions lead to the subject of benchmarking where one has to determine broad comparability criteria and carry out comparability adjustments to eliminate distorting impacts of differences between the transaction of the controlled taxpayer and the transactions between independent companies that are used as a reference.

Suppose for example that a product that is sold between affiliated companies does not carry a brand name. There are physically almost identical products also sold between independent companies. If they are branded, a direct price comparison is hardly possible, because one cannot determine the effect of the brand names on their prices. If, however, none of the products is branded but if there are only differences in sales volume, then it might be possible to determine volume discounts and eliminate the distorting impact on the price. The first example leads to the comparability requirement that the products used for a direct price comparison should not carry marketing intangibles. The second case provides an example for a comparability adjustment.

It is worth noting that this problem might become unimportant if a different transfer pricing method is used. If, for example, the dependent buyers and resellers perform the same functions as the independent buyers and resellers, then one would expect that they earn the same distribution margin regardless of the product differences. The application of the resale price method might then be appropriate. 
The arm's length standard vrescribes a test, and. as a matter of fact, a difficult one

Let me please emphasize that the arm's length standard describes the principles of a test. To prove that intercompany transfer pricing is arm's length and therefore tax acceptable, one basically has to demonstrate that the same prices, gross or net margins would be realized if these transactions occurred between independent parties. With the exception of the profit split method (at least partly) and the cost sharing method, all transfer pricing methods refer to the world outside the multinational enterprise. This is why besides "comparables analysis" some people talk about "outside evidence". The ultimate arm's length test is an economic one founded in reality.

After this conceptual introduction, I would like to explain the arm's length standard and the practical problems associated with it in an unusual way by using an exam question from my last course:

\begin{abstract}
"Your father wants to treat you as a fully grown-up person and starts to charge you 800 Guilders for your little room in your parent's house. You believe that this is much too high. On the other hand you would like to stay at home and enjoy the family life you have been enjoying for the last 40 years. Having recently attended the course on international transfer pricing you want to establish a truly arm's length price.
\end{abstract}

This little example exhibits all the features that occur in transfer pricing for multinational enterprises. First of all it is a non-arm's length situation. There are probably not many families that have strangers participate in all aspects of the family life. Still the task is to determine market valuations and prices for the goods, services and intangibles received in this family relationship. The starting point is to determine the goods and services received. The list is fairly extensive and comprises letting the room itself, cooking meals, the laundry, access to cable TV, water and heating and many more items. There might even be services provided for which the father wants to charge money but from which the 
son or daughter does not receive any benefits. The next step is to quantify the volume of these transactions, e.g. how much living space, how much heating, or how many meals are provided.

These goods and services have to be priced now. In some cases, like the use of the telephone, charging the direct cost for calls is clearly appropriate. The recovery of the fixed cost already poses a problem, because the student would have to cover that in its entirety if he had his own phone. The pricing of meals with reference to the university's dining hall or outside restaurants will require comparability in terms of timeliness, quality and quantity. If this is not possible one might attempt to build up a cost chain for material and labor and add an appropriate profit markup. This decomposition of the problem leads to the questions of how to quantify the components properly reflecting the circumstances of receiving that service. To determine an arm's length rent for the room itself one has to identify comparable accommodation. Space, access to garden, closeness to the university and many other factors determine comparability.

Clearly, this case is not meant seriously, in particular, the student's age is not representative. The problem posed is, however, a non-trivial one. There are numerous goods and services provided, some of them interlinked. Various methods can be used, both cost-based and market price-based methods. Issues of cost allocation and the use of full versus marginal cost arises. When applying market-based methods, one has to ensure comparability of the arm's length transaction with the family situation. If this is not entirely possible, one has to determine the effect of any differences on the price to be charged. I would like to invite you to think about this example at your leisure. It has some surprises in store.

Let me please come back to the situation of a multinational enterprise and the general economic principles underlying transfer pricing methods. Consider the extremely simple situation where one group member develops and produces a high-tech product. It sells its products to affiliated sales companies of the multinational enterprise which in turn resell 
it to non-affiliated retailers or end-customers. Because of the technological contents, the product will be unique and it will be impossible to find comparable market prices, as was also argued above for the branded products. For the same reason it will not be appropriate to compare the developing and manufacturing company's profit or cost markup with those of independent manufacturers. The most appropriate and most reliable test of the arm's length standard is to apply the resale price method and to compare the affiliated companies' distribution margin with that of independent companies. If, on the other hand, the product is low-tech and the sales company adds the intangible in form of a brand name, perhaps then the test of the manufacturing company is the preferred approach.

The selection of the tested party and the transfer pricing method to be applied is driven by the economic ownership of intangibles

Obviously the choice between the affiliated companies to be tested and the various transfer pricing methods is crucial in terms of application and results. This important choice is driven by the allocation of the intangibles, and more generally the functions performed, risks taken and assets employed in the multinational enterprise. I tend to believe that the questions of who in the group owns the intangibles, how to determine the ownership, and how to deal with the transfer pricing consequences is the single most important economic issue in transfer pricing.

In fact, when transfer pricing practitioners refer to the ownership of intangibles within a multinational enterprise they seldomly refer to legal ownership but rather to "economic ownership". Economic ownership focuses on which party actually incurred the costs and the ex ante risks for developing the intangibles. This is being made explicit for cost sharing agreements. In cost sharing agreements two or more parties share the funding of, for example, the research and development work. If the research and development fails, they lose their money. Because they share the costs and ex ante risks they all become the economic owners of the developed intangibles and are entitled to the profits from exploiting those intangibles, even though only one of them might be the legal owner. 
The same approach to economic ownership of intangibles is also applicable in other areas, for example, for marketing intangibles. Practically speaking, it is, however, very difficult to determine who the economic owner is. In fact, this in turn might depend on the transfer pricing system. In our example the manufacturer could choose to refund the sales companies' marketing efforts through the transfer price. If the sales company fails to raise prices or volume (and therefore ultimately group profit) through its marketing effort in a sustainable way, it might still eam an appropriate distribution margin. In this case the manufacturing company effectively absorbs the risk of the unsuccessful marketing effort. If the development of the marketing intangible is successful, the manufacturing company would also obtain the profits because the transfer price would risc with the sales of the sales company. Whether failure or success, the sales company would still only earn a normal margin, whereas the manufacturer incurs the risk and is entitled to the resulting extra profits or otherwise.

This is also an interesting example of how multinational enterprises can structure the allocation of intangibles amongst the group companies through transfer prices.

Furthermore, a consistency requirement arises: transfer pricing determines the ownership of intangibles, which in turn drives transfer pricing, for example through the choice of the selected transfer pricing method.

In international transfer pricing, the paradigm of price formation is reoresented by the profit solit method, which determines the transfer price based on the level of intangibles economically owned by the parties involved in the transaction

The issue of economic ownership of intangibles and their economic treatment goes even a step further. If in our example of a multinational enterprise both sides have important intangibles, e.g. product and marketing intangibles, then neither the manufacturer nor the sales company can be tested alone. This is precisely the case where the profit split method applies. The consolidated profit of the entire group is split according to the relative 
contributions each party makes to the overall success of the group. These relative contributions to the overall success in tum depend on the intangibles involved. It is often impossible to properly value these intangibles. Instead one can capitalize the expenses and determine an intangible asset. The consolidated profit is now split according to the intangible capital of each party. Admittedly, this is only an approximation. It is based on the view that the development of intangibles is an investment that requires a retum.

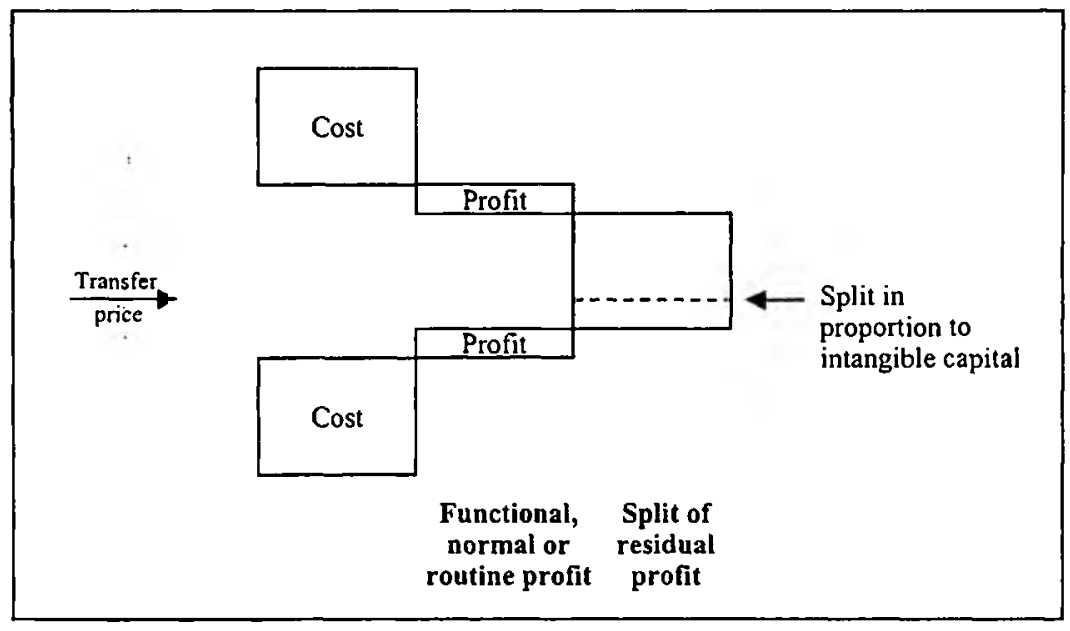

Residual profit split between an affiliated seller and buyer

Let me describe the profit split logic more bluntly. Imagine a double branded product, for the sake of the argument imagine an IBM computer with an Intel chip. The entire computer with the chip is sold for a certain price in the marketplace. But what is the price that Intel charges for the chip and that IBM in our example is willing to pay? The profit split logic says that the price for the chip is such that both IBM and Intel would earn the same retum on their respective investments. 
There is some intuitive appeal to it, but from a conceptual standpoint this is not quite satisfactory. One issue is that investment decisions are based on expectations of a return on that investment, an expectation which might not be fulfilled in the end. Also the assumption that both intangibles implicitly own the same retum is questionable in the light that they might represent different risks and have different gestation periods and economic lives.

But let me come back to the issue of the allocation of intangibles between the group companies and what this means for the interpretation of the transfer pricing methods. Consider again the initial example, where the sales company does not own intangibles and acts as an agent on behalf of the developing and manufacturing company. Then the sales company has no substantial impact on the group's overall success, which is largely determined by the intangibles created by the developing and manufacturing company. It is this company who is the entrepreneur in the group whereas the sales company performs routine functions. As a consequence, we have argued that the sales company should receive a normal distribution margin, which leaves the opportunity for entrepreneurjal profits (and losses) with the manufacturer. The same result emerges when applying the profit split logic, because the sales company has no intangibles and is therefore only entitled to a normal or routine profit.

This argument indicates that the profit split expresses the general economic principle that is used in transfer pricing to explain the formation of prices. If in our simple example of a multinational enterprise the manufacturer has no intangibles the transfer price would be very low, just allowing the manufacturer to earn a normal retum on its capital employed. If then the portion of intangibles that is owned by the manufacturer increases, also the transfer price increases, up to the limit where the manufacturer owns all the intangibles and where now the sales company is allowed to earn only a normal retum on its business. I am not entirely convinced that this logic is familiar to all practitioners and it was therefore an interesting topic for a masters thesis. 
Although the price formation between independent parties is based on expectations, this does not preclude taking an ex post standpoint

Price formation between independent companies in general and also based on the profit split logic in particular is likely to be based on expectations. On the other hand, the test of the arm's length nature of transfer prices can often not be carried out with reference to the expectations of the companies involved. This creates tension between ex ante expectations and ex post results which therefore leads to a very interesting and important debate in intemational transfer pricing. It appears that there are two schools of thought. One school focuses on the result: Is the price, gross margin or net margin that was realized in the controlled transaction the same as the price, gross margin or net margin that was realized in the comparable independent transactions? The other school of thought argues that not the result matters so much but rather, how the controlled transaction was structured. If it was structured in the same way that independent companies would structure their transaction, the transaction is arm's length. This standpoint is supplemented by the argument that everybody has to determine transfer prices in advance and that everybody has to stick to the initial contracts. Whereas the first school would calculate profit splits on an ex post basis, the second school would determine the transfer price based on the expected results of the profit split and then freeze the transfer prices for the years to come.

Clearly, both positions have their merit. Personally, I am in favor of taking the ex post view. First of all there is a very simple, practical reason. It is much easier to determine the actual results of controlled and uncontrolled transactions than to establish that both are based on the same contractual arrangements. Secondly, there are examples where independent companies renegotiate contracts or where they negotiate contracts for the future which gives one party at least a partial compensation for shortcomings in past performance. 
But there is a more fundamental reason from my perspective, which in fact stems from the arm's length standard itself. The arm's length standard asks what the outcome would have been if independent parties had done business under the same conditions and circumstances as the members of the multinational enterprise. Now, affiliated companies have more possibilities of how to structure their relationship. For example they share profit \& loss and balance sheet data. They have common and integrated budgeting and planning processes. In short within the multinational enterprises the transaction costs are much lower than between independent companies. This is one element of economies of integration. Furthermore, multinational enterprises often do not use transfer pricing for local performance measure so that transfer pricing has little incentive effects. For this reason, group companies can more easily write contingent contracts. If independent companies had the same possibilities they would use that tool to improve the risk sharing between them and the contingent contract would allow ex post price adjustments.

The discussion regarding expectations and actual, ex ante and ex post, has also been addressed in court cases on international transfer pricing. Over many years, a sales company of a multinational enterprise made low profits and even losses. This situation was defended by the company that it is normal business conduct between independent parties to honor contracts, and furthermore, that it is normal to incur startup losses. The court took an economic standpoint. It was argued that in the case of sales companies the exit costs are relatively low. One can therefore expect that an independent and prudent businessman would terminate his business rather than incurring low profits or even losses over such an extended period of time without any hope for improvement. The court concluded that after a certain period of time, an affiliated sales company should earn a positive return. 
There is a verv important link between entrepreneurial risks and the economic ownership of intangibles

Such considerations of startup situations are very important in international transfer pricing but have not yet been dealt with properly. As demonstrated above the tax authorities fear that this argument is used as an excuse for reducing the newly founded company's profit. On the other hand, in a business environment, startup losses are common. The real underlying issue is again about intangibles. A company starting up its business in a market has to develop name recognition, a retail network, educate the local labor force, adopt the product to local requirements, or perhaps develop supplier relationships and manufacturing processes. One could argue that it has to develop certain intangibles to be successful in the market. This is costly and takes time. And it is risky, because it may fail as many real life examples show.

In light of our previous arguments, this company becomes the owner of intangibles and should be allowed to reap any benefits afterwards. The multinational enterprise may elect to structure its internal relationships in such a way but then it also has to make sure through the transfer pricing system that the new company can obtain the return on its investment. However, there is an important difference between an affiliated group of companies and independent companies. If the startup fails for an independent company, it will go bankrupt. If the same happens to a member of a multinational enterprise, the group typically will support it. Effectively, someone else takes over the risk of failure. In such a case, who is the true economic owner of the intangibles developed in the new market? I anticipate that this kind of discussion will become more and more important when multinational enterprises enter developing countries, which then might realize the importance of transfer pricing.

I just would like to point out that the multinational enterprise can overcome the above problem. Through its transfer pricing system, another company, e.g. the parent company, can take over the starup risk and fund the development of the intangibles. The startup 
company itself obtains a routine profit from day one. As a consequence, any additional profits generated for the group in this new market should not remain with the startup company but with the other affiliated company, which also took over the funding and the risk for developing the new market.

The economic ownership and the allocation of entrepreneurial risks are the overriding considerations for concept design. choosing the tested partv. and selecting the most appropriate transfer pricing method for testing the arm's length nature of transfer orices

The conceptual discussion so far has important practical implications. The observed allocation of intangibles and entrepreneurial risks determines the choice of the tested party and the selection of the transfer pricing method. In a nutshell, affiliated companies that own major intangibles or incur entrepreneurial risks should be given the corresponding opportunity to earn entrepreneurial profits or otherwise. They are typically not selected as the tested party. The other companies should earn a normal or routine profit in accordance with their own routine functions, risks and assets. This is to be tested by applying standard transfer pricing methods using a comparison of prices, gross margins or net margins.

It follows that the allocation of intangibles and risks also drives the design of an economically sound transfer pricing system. It should be kept in mind that the multinational enterprise has considerable freedom in the allocation of such intangibles and risks. It can decide about who funds the development and incurs the ex ante risk and therefore becomes the economic owner with a corresponding profit entitlement (not guarantee!). It can choose between admissible transfer pricing methods such as licensing or cost sharing. In fact, the choice of the transfer pricing method may impact on the economic ownership of intangibles. It goes without saying that these choices have a substantial impact on the profit allocation amongst the entities of the multinational enterprise. 
I would like to mention as an aside that the allocation of "normal" risks is the second most important design feature for a transfer pricing system. There are numerous possibilities to structure the risk sharing between the buying and the selling company. A firm could just provide a contract service at a risk free profit or be left with some market risk and earn a profit that compensates for that risk.

Economic and business logic is also heavilv used for comparabilitv adiustments

Many of the examples given show that transactions can be structured in different ways. Despite the fact that they might be broadly comparable, differences remain that have an impact on the resulting prices or margins. To the greatest extent possible, these distortions have to be eliminated to arrive at the required reliability of the application of the arm's length standard.

Consider for example the resale price method, which compares the gross margin of the affiliated sales company with that of independent and broadly comparable independent sales companies. Precisely comparable companies will hardly exist so that differences in the functions performed, the risks incurred or the assets (including intangible assets) employed will remain between the affiliated sales company and the selected independent companies. The affiliated company may not have a warehousing function, whereas the independent companies have one, there may be different exposures to exchange rate risks, or working capital levels. These differences have an impact on the observed distribution margins and lead to an unfair comparison. This is the reason why the arm's length standard requires that the same transactions under the same circumstances be considered. Now if it were possible to quantify all these differences and develop appropriate adjustment logics for them, then one would arrive at a highly reliable determination of an arm's length transfer price.

Without being exhaustive, I just want to mention a few comparability adjustment approaches. Differences in inventory levels between the tested party and comparable 
uncontrolled companies lead to differences in the financing requirements. To quantify them it is common practice to value the difference in inventory days by using the theoretical weighted average cost of capital (WACC) derived from the capital asset pricing model (CAPM). Regression techniques have also been proven successful, when it is not possible to derive on theoretical grounds satisfactory relationships between cost or margin drivers and the margin itself. Often, statistical analyses even enable the determination of the actual cost or margin driver from a set of potential drivers in the first place.

\section{The comnarability adiustments lead to an arm's length range}

The purpose of carrying out comparability adjustments to the comparable parties is to match their functional profile as close as possible to that of the tested party. At the same time the distorting effects stemming from the differences are eliminated. Still, there will be an interval of results, i.e. a range of prices or margins that comparable independent parties would realize for similar transactions and under similar circumstances as those of the tested party. This is called the arm's length range.

There are two reasons for arriving at intervals rather than a single price as could be expected from textbook pricing models. One is that the data for carrying out comparability adjustments may be incomplete. The other reason is that also in economic theory price ranges for a product emerge if the assumption of complete market transparency, efficiency and cost free entry and exit is abandoned. Therefore, in reality, one would also expect a range of prices negotiated between independent firms. .

The question arises of how to interpret the arm's length standard in such a case. Suppose that the results in the arm's length are all equally reliable, then there is no reason to distinguish amongst the points. It should therefore be argued that the transfer prices satisfy the arm's length standard if they fall within the range. 


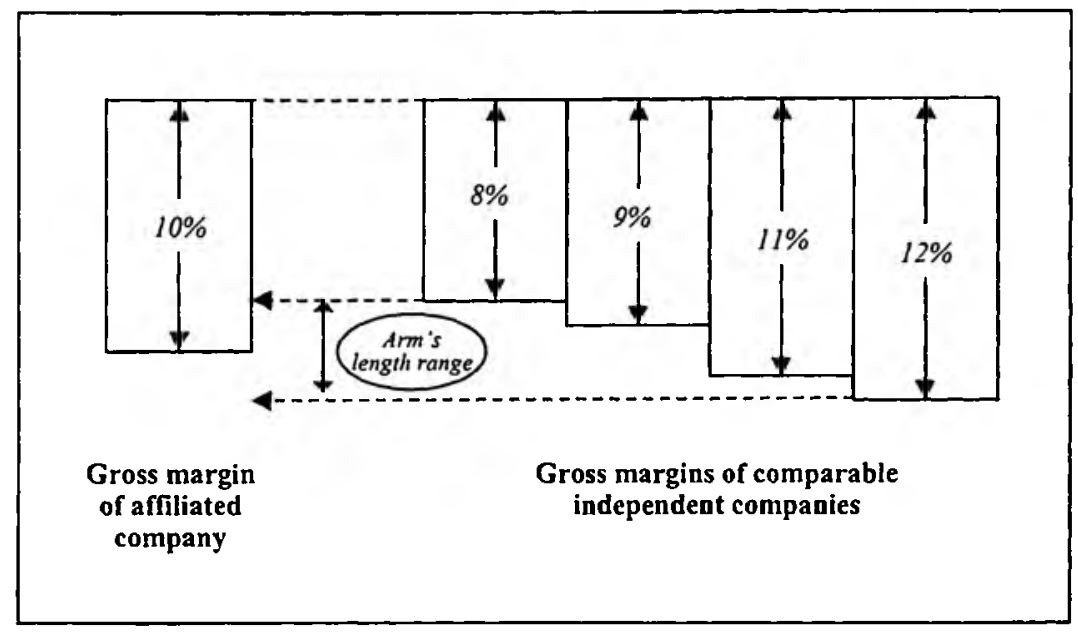

Range concept for the resale price method

There are still substantial economic issues in international transfer pricing that require further discussion

Personally I believe that the arm's length standard is a very good basis for dealing with transfer pricing issues. However, great care should be taken when interpreting it for practical applications and we have already looked at some of the underlying economic principles, application problems, and, in fact, some conceptual problems. In this section I want to go beyond that and address some general economic considerations, because $I$ am convinced that economics and business administration can develop policy recommendations on how to interpret and apply the arm's length standard and they can also point out its strengths and weaknesses. 
Is the profit solit concept really a valid price formation mechanism?

I have pointed out that the profit split logic is in my view the most important economic paradigm in international transfer pricing. The reason is that it describes a price formation mechanism that can and is applied to the transfer of tangible and intangible property. According to this logic the transfer price is determined by splitting the consolidated profit of the parties involved in the transaction according to their contribution to the overall success, which is in practical terms measured as the portion of the total intangible capital they own individually. If one of the parties has no such intangible capital one arrives back at giving that party a normal or routine gross or net margin. In this case of the often applied residual profit split method, this leads to the same result as applying the cost plus, resale price or transactional net margin methods.

When the profit split method is applied to the transfer of intangibles, it determines a royalty to the licensor that leaves profit with the licensee in accordance with the intangible capital employed by the licensee. If the licensee has none, he has to be considered a contract manufacturer, who is only entitled to a normal or routine profit. The licensor will then extract the complete rent in the license agreement. 


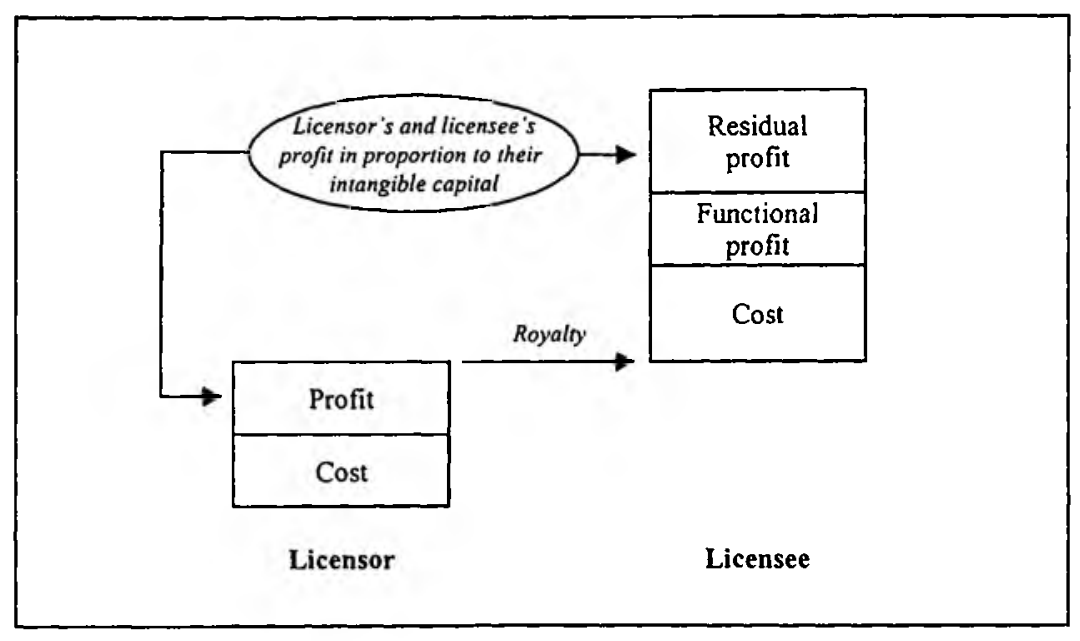

Concept of applying the profit split method to licensing

Basically, in the profit split method, the transfer price allows both parties to recover their respective costs, to earn a normal profit, and to earn the same return on their intangible assets. This price formation rule has some intuitive appeal, but I think it is at odds with standard economic theory. When making the investment decision, the multinational enterprise will consider the investment in, lets say, the product intangibles and the marketing intangibles at the same time. The group will maximize the expected cash flow and has to trade off between the investment of an additional Guilder in product design or marketing activities. This already points out a number of important differences between the theoretical and the practical application. One is that the decision basis is cash flow rather than the capitalized and amortized investment amounts. Another one is that the last Guilder invested in the product design and the last Guilder invested in marketing have the same retum, but the total amounts do not have the same return. The additional issue of expected profits or cash flows versus ex post profits or cash flows might be reconcilable, because it has the additional dimension that affiliated companies can write contingent contracts which might be difficult for independent companies, as mentioned above. 
There is another important difference. The group's investment decision on product design and marketing activities is a joint one and hopefully leads to economies of integration. These synergies arise because typically, maximized profit of the group is higher than the sum of the individual profit if each company were to maximize its individual profit by a standalone investment decision. The profit split suggests to split this profit element that arises from the joint investment decision in proportion to the underlying individual intangible assets. From an economic perspective this problem is very similar to allocating common costs. Using standard bargaining models, like Rubinstein or Nash Bargaining the result is, however, a 50:50 split of this common profit.

Because of the crucial importance of the assumptions on the price formation in international transfer pricing, I hope that economic theory will be able to provide sound and practical concepts in the future.

A general problem of price formation mechanisms in international transfer pricing is that they have to exclude incentive effects of market prices between independent firms

Problems arise in the application of the arm's length standard but also in the development of economic models that try to describe the price formation between independent parties if they were in the same situation as affiliated parties. In my view, this is because the different purposes of the prices are mixed up. A price first of all values a product sold and bought, an intangible, or a service rendered. This is the primary focus in international transfer pricing. Between independent parties, prices also provide incentives and, through their impact on profits, also influence the firms' management decisions. I agree that this distinction between valuation and incentive purposes is artificial because both occur at the same time in markets which, by definition, consist of independent players. Valuation is indeed partly influenced by incentives. For example, a product price might be set relatively low to induce another firm to focus its sales effort on this product. 
However, companies belonging to the same group often use performance measures that are not tied to the profit of the individual companies. To put it more drastically the bonus of local management of a multinational enterprise often depends on criteria that relate to the entire group's performance rather than merely local profit. Budgeting and reporting processes are integrated, and volume, price or sales mix decisions are taken to maximize the group's profit rather than that of the individual companies. I would like to hypothesize that independent firms in such a situation would determine a different transfer price.

Related to the subject of incentives is the issue of risk sharing between the companies. Independent companies probably face a higher bankruptcy risk than affiliated companies, simply because the latter are likely to be rescued by their parent company. Or, independent companies face the risk of having their contract terminated and being replaced by an affiliated company of the group. This is, for example, quite a typical approach when developing a market. As a consequence, one would expect that independent companies eam a return that covers that risk exposure. It is often impossible to quantify this additional profit element and the arm's length standard still forces a comparison of the tested party's return to the independent firm's returns.

International transfer pricing has to struggle with the fact that multinational enterprises can structure their transactions differently from those of independent firms

The way multinational enterprises can structure their intemal incentive systems differently from the incentive structures between independent parties is one example of their greater range of freedom. This clearly also extends to their inter-company transactions. Muitinational enterprises can and do structure their intra-group transactions in a way that would not be chosen between independent companies.

A group perspective is taken to exploit economies of integration, investment decisions, product specialization of production units, capacity utilization within a network of 
production locations, and market allocations. There is an enormous exchange of financial and operational information, there are common budgeting and reporting processes, management personnel is rotated amongst the entities. The multinational enterprise has almost complete freedom in how to allocate functions or risks amongst its entities. To give a dramatic example, in principle, the affiliated sales companies of a multinational enterprise could fund the group's research and development. They thereby become the economic owners of the developed intangibles, which often represent a critical success factor for the group. No enterprise would allow that its independent sales companies become the owner of the research and development results.

Another example is that a multinational enterprise splits the sales of finished goods and the aftermarket sales into two separate organizations. If an independent company were used instead, it would carry out both functions. There are many more examples of where the multinational enterprise structures its intra-group transactions in a way different from that of independent parties. Still the task is to satisfy the arm's length standard for these transactions as they are actually structured by the group, asking and answering the question of what the outcome would have been had this transaction taken place between independent parties. For this purpose, new comparability adjustments may have to be designed to capture the allocation of functions and risks of the affiliated group companies and to base the application of the arm's length standard on a series of decomposed functions and risks.

This freedom in structuring transactions and organizations created an inherent problem in the application of the arm's length standard. It is not appropriate, in my view, that the tax authorities should be allowed to impose any restrictions on the way a multinational enterprise can structure its internal organization, processes, or transactions. Today, this is generally accepted in the regulations and is called the "as-actually-structured" principle, although the regulations mention exceptions to that rule. Furthermore there is a link back to whether to interpret the arm's length standard from a results' viewpoint or whether to focus on the structure of the contractual and commercial relationship. 
There are good reasons why multinational enterprises exist and therefore, there are good reasons why, sometimes, comparable independent companies no longer exist

Quite obviously, the whole issue of how to apply the arm's length standard is aggravated in situations where no comparable independent transactions exist. Multinational enterprises have developed for good reasons. Internalizing market failure is one such reason. Independent manufacturers will not be willing to exclusively produce components for another and let us assume much larger manufacturer, if these components are unique and cannot be used by any other potential buyer and if they require substantial capital investment. In such a case the manufacturer is at the complete mercy of the buyer. In fact, this is historically the reason why the stamping of sheet metal in automotive manufacturing is typically carried out by Original Equipment Manufacturers (OEMs) themselves and not by independent firms. From a transfer pricing perspective, it now becomes unavoidable to look outside the industry or even the country of the tested party to find independent comparable transactions.

\section{Do all methods comply with the arm's length standard?}

I want to make absolutely clear that I do not advocate to abandon the arm's length standard. It is a practical and by and large fair approach to the complex economic problems posed in international transfer pricing. In the discussions that have led up to today's status of the tax regulations in the OECD and in its member countries, substantial progress has been made on the conceptual and the practical side.

However, as you have seen, the arm's length standard has some inherent problems because of the massive structural differences between the dealings of independent companies and the dealings within a multinational enterprise. My personal conclusion so far is, as a practitioner and an economist, that the implicit use of price formations that are based on supply and demand functions is not entirely appropriate. I believe that 
bargaining models should complement today's economic thinking in international transfer pricing, because they more appropriately capture the bilateral monopoly situation of the affiliated buyer and supplier within a multinational enterprise.

Accepting the arm's length standard as a starting point, the question arises whether the transfer pricing methods together with their assumed underlying price formation mechanism suggested in the OECD Guidelines and the various national regulations actually meet this standard. For those methods that directly compare the tested party with independent comparable companies and the transactions between them, this question is less critical. However, we have touched on issues of how to allocate economies of integration, how to deal with inefficiencies, or how to properly interpret the "as-actuallystructured" principle. When discussing the profit split method, this issue became more crucial because of the open question of whether the profit split method describes an economically sound price formation mechanism. When looking at cost sharing as a transfer pricing method for transferring intangible property, the economic assessment of the arm's length nature of the method leads to serious concerns. In fact it turns out that independent companies typically would not choose cost sharing. To put it differently, cost sharing as a method does not seem to comply with the arm's length standard.

In a cost sharing agreement two or more parties share the costs and the ex ante risk of research and development activities. For transfer pricing purposes one has to determine the respective cost shares. The US Regulations, for example, determine that the cost shares be proportionate to the anticipated benefits, i.e. profits, each cost sharing partner would receive from a successful development. To exemplify the situation, consider two manufacturing operations that share the cost of a new product development. The actual $R \& D$ effort is carried out by one of them. If the development is successful, they both produce and sell the new product in their respective markets. If one company earns a profit of 80 and the other a profit of 120 they would share the R\&D cost 40:60. This is the so-called "commensurate with income standard". Referring back to the discussion about bargaining models, it is difficult to envisage that independent firms would negotiate 
such shares. The expected outcome from the standard models is a 50:50 split of the entire consolidated profit.

But beyond that there is also a more important consideration. Independent parties could choose between cost sharing and licensing. Obviously licensing would only occur after the R\&D effort and only if it had been successful. This timing difference is crucial when investigating subgame perfect equilibrium outcomes. Adhering to the commensurate with income standard the company carrying out the R\&D has to offer a cost sharing agreement which shares the cost in proportion to the respective expected profits. It would only be optimal to do so if the cost share exceeds the expected license income in case the product development is successful. For the same token for the other company the expected profit under cost sharing is smaller than the expected profit under licensing. It will therefore decline the cost sharing offer and wait for the second stage and then accept the license offer. On the other hand, if the cost share received is lower than the expected license income, then the company carrying out the R\&D will not offer the cost sharing in the first place. This shows that cost sharing under the commensurate with income standard cannot be a subgame perfect equilibrium outcome. The same applies to any predetermined cost sharing nule. If no restrictions were imposed on the cost sharing agreements, then risk neutral companies would agree on cost shares that give the same expected outcome as under licensing. It can be shown easily that situations arise where such a negotiated cost share to be paid by the non-developer exceeds the entire R\&D cost. It not longer seems appropriate to call this cost sharing, because the non-developer takes over the entire cost and the ex ante risk.

Whereas some forms of the profit split contain elements of outside evidence, cost sharing is based on a purely internal view of the multinational enterprise. This might be why the political debate on cost sharing has taken so long. The severe conceptual problems outlined above are mitigated by substantial practical advantages. Having dealt with both cost sharing systems and license arrangements, cost sharing avoids the very difficult valuation problems in licensing. Unfortunately it also creates buy-in and buy-out 
problems. This refers to situations where, for example, one manufacturer has become the economic owner of a certain product intangible but where the multinational enterprise decides to shift production to another location. Therefore, although it is the economic owner of the intangible, someone else exploits the intangible and the ownership of the intangible should be transferred at a certain price to the new manufacturer.

This is a very good example of the tension between an economically sound and a practical approach. Economics and business management can provide guidance on conceptual issues, practitioners can provide guidance on applicability, but in the end it is a political task to strike the balance.

International transfer pricing is an excellent topic for multidisciplinary and hands on teaching and also for research

From the many examples and arguments that I have presented above, you can easily gather that international transfer pricing is also a reach field for teaching. In my view, it provides a unique basis to combine theory and practice in teaching economics and business administration. It comprises elements of the theory of firms, financial analyses and cost accounting, benchmarking, statistical analyses, and economic models on price setting, bargaining and capital asset pricing. Last but not least tax law and tax regulations have to be interpreted.

To obtain a better understanding of the arm's length standard, it is important to understand why multinational enterprises exist. Some of these reasons have direct implications for the application of the arm's length standard. In cases where multinational enterprises overcome market failures or exploit benefits of vertical integration, it is often the case that directly comparable transactions between independent parties simply do not exist. 
By becoming more familiar with transfer pricing, students can better understand the importance of economies of scale for the concentration and the regional or global deployment of value added activities. The distribution of the value added activities in turn determines the intercompany transaction flows. The students also learn through financial simulations how multinational enterprises influence the distribution of profits amongst the entities through central product allocations to manufacturing units, decisions on capacity utilization, or allocation of produced goods to markets. This is even the case with an appropriate transfer pricing system.

The course provides insights into profit \& loss and balance sheet analysis. Practical examples provide an introduction to the interpretation of profit \& loss and balance sheet positions. The goal is, however, to develop an understanding of how to measure the profitability of firms and how to best compare them. One has to deal with the choice between various profit level indicators, for example return on sales or return on capital employed. This choice is driven by the value stage under consideration, for example the asset intensity of the company. These issues have also been explored in a masters thesis.

Simple regression techniques are applied for comparability adjustments. As an example, used car price offerings in a newspaper and their dependence on the mileage of the car and other car features are analyzed. This then allows the students to determine the price of a car with specified features that is not included in the newspaper. They can compare the result of this approach with those of altemative approaches and critically assess the reliability of the methods.

The concept of margin or profit drivers is introduced which is absolutely crucial for benchmarking. Thereby, a first understanding of this important business management tool is provided.

Price formation including bargaining approaches is discussed and how the transfer pricing guidelines and regulations interpret price formation. The various transfer pricing 
methods are introduced and compared. The rules of application are developed. This also covers licensing which is also important as a means of technology transfer between independent firms.

Intemational transfer pricing provides interesting topics for master theses. In fact, students have written their master theses on cost sharing and licensing, profit level indicators, or have analyzed the profit split method.

\section{Epilog}

International transfer pricing is an interdisciplinary subject where economics and business administration provides conceptual guidance and practical interpretations of the law. Symergies between academics and practice, I believe, are worth exploiting.

I would like to thank the University of Maastricht, and in particular the Faculty of Economics and Business Administration, for providing me with the opportunity to teach here. It was quite natural for me, working as an economist in international transfer pricing, to choose this as the topic for a course in quantitative economics when I was asked to become a professor at the University of Maastricht. This initiative came from Franz Palm who was interested in a course that combines theoretical aspects in economics with real life applications. My name was mentioned by Martin Hellwig, with whom I had written my Ph.D. thesis at the University of Bonn. As a result of these fortunate coincidences, I have been giving courses on international transfer pricing for four years now.

During this time, other forms of cooperation arose. For example, I had the opportunity to lecture in seminars together with Anton Daniels from the Faculty of Law. This gives you a clear indication that intemational transfer pricing is an interdisciplinary subject and I hope that more opportunities for interdisciplinary work and cooperation will emerge. 
At this point, I would also like to add a word of thanks to my employing company,

A.T. Keamey, and my family. Without their consent and support, I would not be able to teach on transfer pricing here at the University. I also would like to thank Hans Peters for his support and friendship.

Dealing with international transfer pricing is hard work, brain work and also fun. I hope that now, after my speech, you share my interest in this subject.

Thank you for your attention. 


\section{References}

The following list contains selected reading material on intemational transfer pricing in business, economics, and teaching:

Broecker T. Lump sum license Fee arrangements are the arm's length equivalent of cost sharing arrangements. Joumal of Financial Management and Analysis 1995; 8.1: 58 - 67

Broecker $T$. Is cost sharing under the commensurate with income standard actually arm's length? Meteor Research Memorandum 1995: RM/95/002

Brouwer M. Transfer pricing methods under review: TNMM as best method. Master thesis, University of Maastricht, 1996

Caves RE, Crookell H, Killing JP. The imperfect market for technology licenses. Oxford Bulletin of Economics and Statistics 1983; 45: 249 - 267

Dunning $\pi$. Multinational enterprises and the global economy. New York: AddisonWesley Publishing Company, 1993

Keuven R. Cost sharing arrangements for R\&D. Master thesis, University of Maastricht, 1996

King E. Transfer pricing and valuation in corporate taxation. Boston/Dordrecht/London: Kluwer Academic Publishers, 1994

Mogle JR. Intercompany transfer pricing for for intangible property. Tax Management Transfer Pricing 1994; 2.18: Special Report No. 11 
Mulders AW. Equivalence of profit split method and other transfer pricing methods. Master thesis. University of Maastricht, 1996

OECD Committeee on Fiscal Affairs. Model tax convention on income and capital. Paris: OECD, 1994

OECD Committeee on Fiscal Affairs. Transfer pricing guidelines for multinational enterprises and tax administrations. Paris: OECD, 1995 (latest update: 1997)

Roth AE. Axiomatic models of bargaining. Berlin: Springer Lecture Notes in Economics and Mathematical Systems No. 170, 1979

Rubinstein A. Perfect equilibrium in a bargaining model, Econometrica 1982;50.1

US Department of the Treasury, Intemal Revenue Service. IRS final $\$ 482$ regulations for intercompany transfer pricing. Washington, 1994 